FACTA UNIVERSITATIS

Series: Physical Education and Sport, Vol. 18, No 1, 2020, pp. 25 - 36

https://doi.org/10.22190/FUPES200314004K

Research article

\title{
PERCEIVED AUTONOMY, THE MOTIVATION CLIMATE AND INTENTION FOR PHYSICAL ACTIVITY: A COMPARATIVE STUDY OF STUDENTS BASED ON THEIR GENDER AND EDUCATIONAL LEVEL
}

\author{
UDC 796/799 \\ 159.9
}

\author{
Dimitrios Karaoglanidis, Katerina Mouratidou, \\ Panagiotis Kanellopoulos, Sofia Karamavrou, Ioanna Parisi
}

Department of Physical Education and Sport Science, Aristotle University of Thessaloniki, Serres, Greece

\begin{abstract}
The main aim of the present study was to examine whether perceived autonomy during physical education (PE) classes, the perceived motivation, and students' intentions for physical activity outside of school differ based on their educational level and gender. The sample consisted of 551 children (266 boys and 285 girls), of which 320 were attending primary school and 231 were attending high school. Four instruments were used for collecting data: (a) a demographics questionnaire; (b) the Perceived Autonomy Support in Physical Education scale (P.A.S. in PE) for assessing students' motivation; c) the Learning and Performance Orientations in Physical Education Classes Questionnaire (LAPOPECQ) for assessing the perceived motivational climate within the PE class, and (d) a questionnaire based on the Theory of Reasoned Action which assessed the participants' intentions for physical activity outside of school. The results showed that as children grow up and change educational levels, the perceived motivational climate with an emphasis on tasks, the sense of autonomy in PE, and the intention to exercise are on the decline. In addition, it appeared that girls exhibited less intention to exercise compared to boys, especially in the highest level of education, and were more likely to perceive the motivational climate in the PE lesson as taskoriented rather than ego-oriented. To sum up, the gender and educational level of students are considered two key factors for both motivation and a sense of autonomy in PE, as well as for their intention to exercise outside of school.
\end{abstract}

Key words: Motivational Climate, Perceived Autonomy, Physical Activity Intention, Educational Level, Gender

Received March 14, 2020/ Accepted April 10, 2020

Corresponding author: Dimitrios Karaoglanidis

Department of Physical Education and Sport Science, Aristotle University of Thessaloniki, Agios Ioannis 62100 Serres, Greece

Phone: + 302321067135 • E-mail: dimiskarao@ gmail.com

(C) 2020 by University of Niš, Serbia | Creative Commons License: CC BY-NC-ND 


\section{INTRODUCTION}

Nowadays, it is well documented in the literature that the levels of students' internal motivation, as well as their willingness to participate in Physical Education (PE) classes decrease as they grow older and move from elementary to high school, with the tendency to decrease even further during the last years of high school (Harter, 1981; Papaioannou, 1997; Otis, Grouzet, \& Pelletier, 2005; Pate, Schenkelberg, Dowda, \& McIver, 2019). There is also a great concern about the number of children and adolescents adopting a sedentary lifestyle (Biddle, Sallis, \& Cavill, 1998; Li et al., 2018), since inadequate activity not only has a direct adverse effect on children's health (Sallis, Patterson, Buono, \& Nader, 1988), but also on their long-term health as adults (Sallis \& McKenzie, 1991). However, as it has been shown in relevant studies (Shephard \& Trudeau, 2000), an active post-adulthood lifestyle has its roots in adolescence, whereas PE can influence young people in their decisions about sports in the future (Coakley \& White, 1992).

It is clear from the above mentioned, that in order to establish the importance of physical activity in everyone's consciousness, the corresponding habits for health and quality of life should be instilled from an early age (Sallis \& Patrick, 1994; Telama, Yang, Laakso \& Vilkari, 1997; Del Pozo-Cruz et al., 2019). It is for this reason that PE and the influence of the PE teacher play a key role in school life, not only in cultivating motor and cognitive skills, but also in improving the quality of students' life in the present as well as in the long term (Sallis \& McKenzie, 1991; Wright, Patterson, \& Cardinal, 2000). Towards this direction, supporting students' intentions and exploring all of the factors that may influence children's motivation and commitment to physical activity can act as a positive reinforcer (Taylor \& Lonsdale, 2010).

One of the widespread psychological theories that examined and interpreted the factors responsible for manifestation and/or behavior change, is the so-called Theory of Reasoned Action-TRA (Ajzen \& Fishbein, 1977; Breslin, 2018). According to the TRA, the appearance of a behavior depends on whether or not the individual is willing to manifest it. Intention, in turn, is predominantly determined by one's attitudes toward a certain behavior, where one's attitude represents the individual's overall assessment of his/her behavior (Ajzen, 1985) and by social role models and the perceived social pressure which guides an individual into adopting or rejecting a certain behavior (Dzewaltowski, Noble, \& Shaw, 1990). It is important to notify that the evolution of TRA is the so-called Theory of Plan Behavior-TPB (Ajzen, 1988; 1991; Zhang, Gu, Keller, \& Chen, 2019), which has been recognized as a highly effective theoretical framework for interpreting individuals' attitudes toward physical activity (Blue, 1995; Hausenblas, Carron, \& Mack, 1997).

Further, one of the major theories for the study of motivation in education is the SelfDetermination Theory - SDT developed by Deci and Ryan (1985), and developed worldwide, as it has been extensively studied and established experimentally from a multitude of researchers (Deci, Vallerand, Pelletier, \& Ryan, 1991; Pelletier et al., 1995; Ivanović, Milosavljević, \& Ivanović, 2017). Based on this theory, an attempt was made to determine the degree of motivation of a person, stemming from the individual himself/herself (internal motivation) rather than extrinsic factors (external motivation). This identifies how one feels about regulating their own behavior by themselves, and the more they feel they can regulate on their own, the higher their self-esteem is exhibited (Deci \& Ryan, 1985). This theory highlights the social factors that a teacher needs to incorporate into his/her teaching style, in 
order to satisfy three basic psychological needs of the students (Deci \& Ryan, 1985; Ryan \& Deci, 2008; Ryan \& Deci, 2017). These psychological needs are: a) The internal need for autonomy, which refers to one's desire to act autonomously and to decide on one's own actions (Deci \& Ryan, 1985; Ryan \& Connell, 1989; Sun, Li, \& Shen, 2017); b) the need for perceived competence - the ability that relates to one's desire to interact effectively with one's environment and to confirm one's abilities by demonstrating them (Deci, 1975; Harter, 1983; Koka \& Sildala, 2018), that leads individuals to look for challenges which correspond to their abilities; and c) the need for good social relationships, which relates to trying to build positive relationships with other people in their environment, to care for them and to feel that they care for him/her too and to feel a sense of belonging with these individuals in a community (Baumeister \& Leary, 1995; Hilland, Ridgers, Stratton, Knowles, \& Fairclough, 2016).

A review of the relevant literature showed that although there is a relatively large amount of research on motivation and intention for physical activity, gender and age as parameters that could be related to these two variables (motivation, intention) were not investigated sufficiently.

Therefore, the main aim of the present study was to examine whether perceived autonomy during PE classes, the perceived motivation, and students' intentions for physical activity outside of school differ based on their educational level and gender.

\section{METHODS}

\section{Participants}

The study involved 551 students, aged 11 to 18 years ( $M=12.90 \pm 2.73$ years), of whom 266 were boys $(48.3 \%)$ and 285 girls $(51.7 \%)$. The total sample consisted of 320 students $(58.1 \%)$ attending the last two grades of elementary school and 231 students $(41.9 \%)$ attending to the last three years of high school (Table 1).

Table 1 Baseline anthropometric characteristics of the participants

\begin{tabular}{llcc}
\hline Sample Size & & $\mathrm{N}$ & $\%$ \\
\hline Educational Level & Primary School & 320 & 58.1 \\
& High School & 231 & 41.9 \\
\hline Gender & Boys & 266 & 48.3 \\
& Girls & 285 & 51.7 \\
\hline & Total & 551 & 100 \\
\hline
\end{tabular}

\section{Design of the study}

Purposive sampling was used to select the sample to ensure "special composition" in the sample groups. The anonymity of the students was ensured by using a code instead of the students' name. Questionnaires were completed in the classroom under the supervision of researchers and lasted $20 \mathrm{~min}$. Initially, the students were informed about the procedure and how to complete the questionnaire. In the meantime, it was emphasized that participation in the research is voluntary, that the questionnaire is anonymous, that the children's responses will be kept confidential and that the resulting data will be used solely for the purpose of the research. The possibility of students leaving at any time they wish was also stressed and it 
was clarified that this could be done without any requirement or other obligation on their part. Finally, it was explained that the purpose of the questionnaire was to improve the quality of the lesson rather than the students' grades and assessment.

\section{Questionnaires}

In this study, a total of 4 questionnaires were merged into one. More specifically, the measuring instruments were:

A questionnaire of demographics to gather information regarding gender, age and education level;

Perceived Autonomy Support in Physical Education - P.A.S. in PE (Hagger et al., 2007) for assessing students' motivation based on the theory of self-determination. Specifically, the PAS in PE consists of 12 closed-ended questions and participants are asked to answer on a 7-point Likert scale from 1 "strongly disagree" to 7 "strongly agree". An example of a statement is "I can freely express to my PE teacher during the course". Validation and reliability testing in the Greek version were conducted by Hagger and colleagues (2007);

Learning and Performance Orientations in Physical Education Classes QuestionnaireLAPOPECQ (Papaioannou, 1994) on Climate Motivation Perception in the Physical Education Course. It is composed of 27 items and has two dimensions: Perception of motivational climate, which includes the task/learning climate (13 items) and Perception of motivational climate, which includes the ego/performance climate (13 items). Students had to answer on a 7-point Likert scale from 1 "strongly disagree" to 5 "strongly agree". An example of a statement is "students fear failure in exercises because it would disapprove of others". The questionnaire has been developed and applied to the Greek school population by Papaioannou (1997);

Intention for Physical Activity: A questionnaire consisting of 3 questions was designed to assess the intention of students to exercise outside of school and was based on the theoretical background of the TRA and TPB. An example of a statement is "I plan to continue to train regularly for the next 6 months". Students had to answer on a 7-point Likert scale from 1 "strongly disagree" to 5 "strongly agree".

\section{The main hypotheses of the study}

The main hypotheses of the study were: elementary school students compared to high school students would score higher on the perceived task-oriented motivational climate (hypothesis 1), as would girls compared to boys (hypothesis 2). High school students will perceive the motivational climate in PE more towards ego orientation rather than task orientation (hypothesis 3), as would boys compared to girls (hypothesis 4). Concerning perceived autonomy, elementary school students are expected to score higher on perceived autonomy than high school students (hypothesis 5). Finally, intention to exercise is expected to be higher in elementary school students than in high school students (hypothesis 6) with boys showing higher levels than girls (hypothesis 7). 


\section{Data analysis}

To explore the role that independent research variables can play, namely the gender of pupils and their age/educational level, on the dependent one (i.e., perceived ego- or taskoriented perceptions of self-perception during the PE lesson, and intention to do physical activity outside of school) four two-way $2 \times 2$ ANOVAs were conducted. In all cases, the level of statistical significance was set at $\mathrm{p}<.05$.

\section{RESULTS}

\section{Descriptive Statistics}

Descriptive statistics of the study's variables are shown in Table 2 and Table 3. The first impression given by the descriptive statistics on motivational orientation is that there appears to be a preference of elementary school students towards task orientation, i.e., TASKPRIMARY $=4.29 \pm .51$ vs. TASKSECONDARY $=3.63 \pm .60$ (Mean \pm SD). The reverse occurs regarding the ego orientation, i.e., TASKPRIMARY $=2.55 \pm .69$ vs. TASKKSECONDARY $=2.7 \pm .62(\mathrm{Mean} \pm \mathrm{SD})$. On the other hand, in terms of gender, the difference is mainly in task orientation with an apparent superiority of girls, whereas in ego orientation boys show marginally higher values. Specifically, TASKGIRLS $=4.08 \pm .63$ vs. TASKBOYS $=3.94 \pm .64$ and EGOGIRLS=2.61 \pm .65 vs.. GOBOYS $=2.64 \pm .67($ Mean \pm SD).

Table 2 Mean \pm SD results of task and ego orientation

\begin{tabular}{|c|c|c|c|c|c|c|}
\hline & \multicolumn{3}{|c|}{ Task } & \multicolumn{3}{|c|}{ Ego } \\
\hline & $\mathrm{N}$ & Mean & SD & $\mathrm{N}$ & Mean & SD \\
\hline Primary Education & 312 & 4.29 & .51 & 309 & 2.55 & .69 \\
\hline Secondary Education & 227 & 3.63 & .60 & 223 & 2.72 & .62 \\
\hline Boys & 260 & 3.94 & .64 & 255 & 2.64 & .67 \\
\hline Girls & 279 & 4.08 & .63 & 277 & 2.61 & .65 \\
\hline
\end{tabular}

Corresponding to the perceived autonomy and intention to exercise, it seemed that students attending elementary school exhibited higher values for both variables, i.e., AUTONOMYPRIMARY $=5.20 \pm 1.01$ vs. AUTNONOMYSECONDARY $=4.93 \pm 1.08$ and INTENTIONPRIMARY $=6.18 \pm 1.17(\mathrm{Mean} \pm \mathrm{SD})$. For the two genders the differences were smaller in absolute units with levels of perceived autonomy rising upwards for girls and levels of intent higher in boys, i.e., AUTONOMYGIRLS $=5.15 \pm 1.08$ vs. AUTNONOMYBOYS $=$ $5.02 \pm 1.02$ and $5.86=5.86$ INTENTIONGIRLS $=5.64 \pm 1.54($ Mean \pm SD).

Table 3 Mean \pm SD results of perceived autonomy and intention

\begin{tabular}{lcccccc}
\hline & \multicolumn{3}{c}{ Perceived Autonomy } & \multicolumn{3}{c}{ Intention } \\
\cline { 2 - 7 } & $\mathrm{N}$ & Mean & SD & N & Mean & SD \\
\hline Primary Education & 303 & 5.20 & 1.01 & 319 & 6.18 & 1.17 \\
Secondary Education & 225 & 4.93 & 1.08 & 230 & 5.15 & 1.58 \\
\hline Boys & 256 & 5.02 & 1.02 & 264 & 5.86 & 1.33 \\
Girls & 272 & 5.15 & 1.08 & 285 & 5.64 & 1.54 \\
\hline
\end{tabular}




\section{Inferential Statistics}

As far as the two-way ANOVA with a dependent variable task orientation and independent variables education, grade and gender is concerned, the results showed that elementary school students had significantly higher perceptions of the learning motivation climate than high school children $[\mathrm{F}(1.535)=189.18, \mathrm{p}<.01$, partial $\eta 2=.261]$. Regarding gender, boys had significantly lower perceptions of the motivational learning climate than girls $[\mathrm{F}$ $(1.535)=7.06, p<.01$, partial $\eta 2=.013]$. However, no significant interaction between the two independent variables (educational level, gender) was found $[\mathrm{F}(1.535)=.055, \mathrm{p}=.81$, partial $\eta 2=.00$ ] (Hypotheses 1, 2). In other words, younger elementary school students and girls have higher levels of task orientation than high school students and boys, respectively. However, the interaction between gender and class had no effect on task orientation.

A similar ANOVA 2X2 analysis was conducted with ego orientation as the dependent variable. According to the results, elementary school students showed a statistically significant lower perception of motivational performance than high school students $[F(1,528)=8.41$, $\mathrm{p}<.01$, partial $\eta 2=.016]$, whereas there is no statistically significant gender difference [F $(1.528)=.265, \mathrm{p}=.61$, partial $\eta 2=.00]$ and no significant interaction between gender and educational level as well $[\mathrm{F}(1.528)=.060, \mathrm{p}=.81$, partial $\eta 2=.00]$ (Hypotheses 3, 4). Primary school students, therefore, were not as ego-oriented as high school students. However, there is no difference between girls and boys in both levels but also in connection with gender.

A two-way ANOVA $2 \times 2$ was also conducted with independent variables gender and educational level and with the dependent variable of perceived autonomy. The results showed that that elementary school students scored significantly higher in perceived autonomy values than high school students F $(1.574=9.174, \mathrm{p}<.01$, partial $\eta 2=.017]$ (Hypothesis 5). It is important to underline that elementary school children also had higher rates of perceived autonomy.

Similar findings were shown with the analysis of Gender X Educational level (two-way ANOVA 2×2) with regard to Intention (Hypotheses 6, 7). However, the results in this case differ in their statistical significance. More specifically, a statistically significant difference was found in intention to educational level, with primary students exhibiting significantly higher levels of intention for physical activity than high school students $[\mathrm{F}(1.545)=76.659$, $\mathrm{p}<.01$, partial $\eta 2=.123]$ but also regarding gender, with boys having significantly higher intentions for physical activity than girls $[\mathrm{F}(1.524)=6.029, \mathrm{p}<.05$, partial $\eta 2=.011]$. Finally, the interaction between gender and educational level was also found to be statistically significant $[\mathrm{F}(1.524)=9.872, \mathrm{p}<.01$, partial $\eta 2=.018]$. Elementary school students once again showed an increasing intention to exercise. The same thing happens this time with boys who seemed to choose to exercise more in their spare time than girls. The combination of gender and educational level plays an important role. Thus, elementary school students are expected to have much higher Intention to exercise rates than high school girls.

\section{DISCUSSION}

As it has been shown in previous studies, a) the psychological needs, stated in the Introduction, are positively related and are interconnected by an exercise and learning environment that enhances autonomy (Amorose \& Anderson-Butcher, 2007), and b) a selfdirected learning environment (even within a classroom) that is directed toward autonomy 
reinforces motivation with high self-determination, as opposed to a more controlled-teachercentered environment (Ryan \& Deci, 2008). In addition, it should also be emphasized, the positive relationship of climate autonomy with perceived autonomy, perceived competence, and the relationships that develop among students (Cadorette, Blanchard, \& Vallerand, 1996 as cited in Vallerand, 1997). This fact, combined with the findings of many studies that examined the impact of the autonomous climate on the pedagogical process on students' perceived competence (Trouilloud, Sarrazin, Bressoux, \& Bois, 2006; Álvarez, López, Gómez, Brito \& González, 2017), as well as on internal motivation (Deci, Nezlek, \& Sheinman, 1981), on creativity (Koestner, Ryan, Bemieri, \& Holt, 1984) and on school performance (Boggiano, Flink, Shields, Seelbach, \& Barrett, 1993), but also in the lower likelihood of a student leaving school (Vallerand, Fortier, \& Guay, 1997), indicates how important it is to support the climate of autonomy for PE teachers.

Furthermore, studies in the field of school PE (Vlachopoulosm Biddle, \& Fox, 1996) have adopted the theory of goal achievement in order to examine the relationship between a person's achievement goals with pleasure and inner motivation from activity (Papaioannou \& Theodorakis, 1996). According to that theory, the motivational climate in a classroom can be either task/learning oriented or ego/performance oriented. In the ego orientation (Nicholls, 1989), the criterion of success or failure is to compare one person's achievements to the norms, abilities or performance with those of others and their relevant ranking (Williams, 1994). Ego-oriented people try to bring about results with the minimum effort and feel at a disadvantage when they make mistakes (Dweck \& Leggett, 1988), while after repeated failures they are likely to give up because they cannot feel successful by surpassing others (Papaioannou \& Gouda, 1994). According to the work or task orientation (Nicholls, 1989), individuals set personal goals and try to improve their level of competence. Previous research has shown that there is a high positive relationship between task/learning orientation with interest and pleasure in activity, whereas ego/performance orientation is negatively correlated with pleasure and positively with high levels of cognitive anxiety, boredom and worry (Goudas, Biddle, \& Fox, 1994).

Finally, the issue of learning performance and motivation was also examined in relation to gender, indicating differences between boys and girls, with girls taking the lead (van Langen, Bosker, \& Dekkers, 2006). This differentiation could have been due to different degrees and/or different types of motivation between the two genders, since girls and boys set different goals and therefore approach learning differently. Thus, these different approaches can interpret the gender differences regarding school achievement (Steinmayr, Bipp, \& Spinath, 2011). In this regard, a study by Dekker et al. (2013) examined whether gender could play a role in motive orientation. The results showed that girls were more likely than boys to support task/work-oriented goals (mastery goals) (48\% vs. 39\%) or to avoid ego/performance goals (performance-avoidant goals) (20\% vs. 14\%). It also appeared that boys often adopt task avoidance goals or ego-oriented goals. Also, the same survey found that at the age of 14-19, task avoidance orientation was twice as high in boys than in girls ( $27 \%$ vs. $12 \%$ ). Finally, the results showed that with increasing age, mastery goals decreased (to 36\%), while work avoidance goals increased (to 18\%). These age and gender differences in goal orientations may be a possible explanation for the lower academic achievement of boys compared to girls and indicate the need for early intervention in the way that both genders are motivated. 
The aim of the present study was to examine whether perceived autonomy in the PE class, the perceived motivational climate, and the students' intentions for physical activity outside school vary by their educational level and gender.

The findings of the present study showed that the initial assumptions were greatly satisfied which indicate a better understanding of the role of the motivational orientation and gender to the perceived autonomy and intention of elementary and high school students.

Specifically, with regard to the first two hypotheses, children in lower grades (primary education) as well as girls show higher levels of task orientation than high school students and boys respectively. That is, primary school students had a significantly higher perception of learning motivation climate than high school students, a result consistent with similar research in Greece (Papaioannou, 1997; Digelidis \& Papaioannou, 1999).

Regarding gender, boys who exhibited significantly lower perceptions than girls' learning motivation climate confirm findings in the international literature that girls want to support task-oriented goals more than boys (Soini, 2006; Dekker et al., 2013; Grastén \& Watt, 2016).

Correspondingly, hypotheses 3 and 4 were partially confirmed as it seems that primary school students are not as ego-oriented as high school children (Duda, 1996; Xiang, Lee, $\&$ Shen, 2001), which is not the case between girls and boys of both educational levels. In terms of ego-orientation, the only variable that seems to play a role is the age of children with students attending high school exhibiting higher levels.

Concerning hypothesis 5 , primary school students showed significantly higher perceived autonomy than high school children, in accordance with what has been reported in previous studies (Levy, Polman, \& Borkoles, 2008). This means that younger children are expected to show greater levels of perceived autonomy despite being boys or girls. This finding is also in line with past literature (Lim \& Wang, 2009). The linear negative relationship between age and perceived competence in childhood and adolescence has also been highlighted by Gillet, Vallerand, and Lafrenière (2012) and Cheval, Courvoisier, and Chanal (2016).

Finally, regarding hypotheses 6 and 7, it was found that elementary school students were more likely to exercise in their spare time. This was foreseen by the relevant literature review (Sallis, Prochaska, \& Taylor, 2000). The same holds true for boys more than girls as well as the interaction between gender and educational level. Thus, boys in the lower grades of primary school show a higher intention than girls in the last years of high school.

\section{CONCLUSION}

Summarizing the above mentioned results, it can be assumed that elementary and high school students supported by a climate of learning motivation by their immediate family and/or learning environment are more likely to exhibit higher perceived autonomy and thus an intention to exercise. Due to the fact that girls seem to be much more impressionable by the environment, boys may need to be immersed in a task-oriented motivational climate with work-oriented goals rather than performance. However, it should not be overlooked that girls show less intention to exercise than boys, at least in the secondary level of education. It would be interesting to have a longitudinal study examining whether girls' high motivation for learning influences their intention to exercise in adulthood. It can also be concluded that the higher the students' age and educational level, the lower learning motivation orientation 
and exercise intention they get. Summarizing, parents and teachers are more likely to provide children with less and less autonomy over time, feeling that their children may no longer need it as they grow up and can more easily self-regulate without adult support. Although, another possible scenario for this downward path of perceived autonomy could be due to the mismatch between the expected autonomy that children want to receive over time and the autonomy they actually receive.

\section{REFERENCES}

Ajzen, I. (1985). From intentions to actions: A theory of planned behavior. In J. Kuhl et al. (Eds.), Action control, (pp. 11-39). Springer, Berlin, Heidelberg.

Ajzen, I. (1988). Attitudes, personality, and behavior. Chicago, IL: Dorsey

Ajzen, I. (1991). The theory of planned behavior. Organizational Behavior and Human Decision Processes, 50(2), 179-211.

Ajzen, I., \& Fishbein, M. (1977). Attitude-behavior relations: A theoretical analysis and review of empirical research. Psychological Bulletin, 84(5), 888.

Álvarez, E.F., López, J. C., Gómez, V., Brito, J., \& González, H.A.M. (2017). Influence of motivation and dispositional flow on the intention to do physical activity in adolescents from four countries. Retos, 31, 46-51.

Amorose, A.J., \& Anderson-Butcher, D. (2007). Autonomy-supportive coaching and self-determined motivation in high school and college athletes: A test of self-determination theory. Psychology of Sport and Exercise, 8(5), 654-670.

Baumeister, R.F., \& Leary, M.R. (1995). The need to belong: Desire for interpersonal attachments as a fundamental human motivation. Psychological Bulletin, 117(3), 497-529.

Biddle, S.J., Sallis, J.F., \& Cavill, N. (1998). Young and active? Young people and health-enhancing physical activity-evidence and implications. London: Health Education Authority.

Blue, C.L. (1995). The predictive capacity of the theory of reasoned action and the theory of planned behavior in exercise research: An integrated literature review. Research in Nursing \& Health, 18(2), 105-121.

Boggiano, A.K., Flink, C., Shields, A., Seelbach, A., \& Barrett, M. (1993). Use of techniques promoting students' selfdetermination: Effects on students' analytic problem-solving skills. Motivation and Emotion, 17(4), 319-336.

Breslin, G., Shannon, S., Ferguson, K., Devlin, S., Haughey, T., \& Prentice, G. (2018). Predicting athlete mental health stigma using the theory of reasoned action framework. Journal of Clinical Sport Psychology, 13(1), 103-115.

Cheval, B., Courvoisier, D.S., \& Chanal, J. (2016). Developmental trajectories of physical activity during elementary school physical education. Preventive Medicine, 87, 170-174.

Coakley, J., \& White, A. (1992). Making decisions: Gender and sport participation among British adolescents. Sociology of Sport Journal, 9(1), 20-35.

Deci, E.L. (1975). Intrinsic motivation. New York: Plenum.

Deci, E.L., \& Ryan, R.M. (1985). Intrinsic motivation and self-determination in human behavior. New York: Plenum.

Deci, E.L., Nezlek, J., \& Sheinman, L. (1981). Characteristics of the rewarder and intrinsic motivation of the rewardee. Journal of Personality and Social Psychology, 40(1), 1-10.

Deci, E.L., Vallerand, R.J., Pelletier, L.G., \& Ryan, R.M. (1991). Motivation and education: The selfdetermination perspective. Educational Psychologist, 26(3-4), 325-346.

Dekker, S., Krabbendam, L., Lee, N.C., Boschloo, A., De Groot, R., \& Jolles, J. (2013). Sex differences in goal orientation in adolescents aged 10-19: The older boys adopt work-avoidant goals twice as often as girls. Learning and Individual Differences 26, 196-200.

Del Pozo-Cruz, B., Perales, F., Parker, P., Lonsdale, C., Noetel, M., Hesketh, K.D., et al. (2019). Joint physicalactivity/screen-time trajectories during early childhood: socio-demographic predictors and consequences on health-related quality-of-life and socio-emotional outcomes. International Journal of Behavioral Nutrition and Physical Activity, 16(1), 55.

Digelidis, N., \& Papaioannou, A. (1999). Age- group differences in intrinsic motivation, goal orientations and perceptions of athletic competence, physical appearance and motivational climate in Greek physical education. Scandinavian Journal of Medicine \& Science in Sports, 9(6), 375-380. 
Duda, J.L. (1996). Maximizing motivation in sport and physical education among children and adolescents: The case for greater task involvement. Quest, 48(3), 290-302.

Dweck, C.S., \& Leggett, E.L. (1988). A social-cognitive approach to motivation and personality. Psychological Review, 95(2), 256.

Dzewaltowski, D.A., Noble, J.M., \& Shaw, J.M. (1990). Physical activity participation: Social cognitive theory versus the theories of reasoned action and planned behavior. Journal of Sport and Exercise Psychology, 12(4), 388-405.

Gillet, N., Vallerand, R.J., \& Lafrenière, M.A.K. (2012). Intrinsic and extrinsic school motivation as a function of age: The mediating role of autonomy support. Social Psychology of Education, 15(1), 77-95.

Goudas, M., Biddle, S., \& Fox, K. (1994). Perceived locus of causality, goal orientations, and perceived competence in school physical education classes. British Journal of Educational Psychology, 64(3), 453-463.

Grastén, A., \& Watt, A.P. (2016). Perceptions of motivational climate, goal orientations, and light-to vigorousintensity physical activity engagement of a sample of Finnish grade 5 to 9 students. International Journal of Exercise Science, 9(3), 291-305.

Hagger, M.S., Chatzisarantis, N.L., Hein, V., Pihu, M., Soós, I., \& Karsai, I. (2007). The perceived autonomy support scale for exercise settings (PASSES): Development, validity, and cross-cultural invariance in young people. Psychology of Sport and Exercise, 8(5), 632-653.

Harter, S. (1981). A new self-report scale of intrinsic versus extrinsic orientation in the classroom: Motivational and informational components. Developmental Psychology, 17(3), 300-312.

Harter, S. (1983). Development perspectives on the self-system. In P.H. Mussen (Ed.), Handbook of child psychology: Formerly Carmichael's manual of child psychology, (pp. 275-385). New York: Wiley

Hausenblas, H.A., Carron, A.V., \& Mack, D.E. (1997). Application of the theories of reasoned action and planned behavior to exercise behavior: A meta-analysis. Journal of Sport and Exercise Psychology, 19(1), 36-51.

Hilland, T., Ridgers, N., Stratton, G., Knowles, Z., \& Fairclough, S. (2016). Origins of perceived physical education ability and worth among English adolescents. European Physical Education Review, 24(2), 165180.

Ivanović, M., Milosavljević, S., \& Ivanović, U. (2017). Self-concept as the determinant of physical activity of preadolescents in physical education classes. Facta Universitatis Series Physical Education and Sport, 15(2), 407-420.

Koestner, R., Ryan, R.M., Bemieri, F., \& Holt, K. (1984). Setting limits in children's behavior: The differential effects of controlling versus informational styles on intrinsic motivation and creativity. Journal of Personality, 52(3), 233-248.

Koka, A., \& Sildala, H. (2018). Gender differences in the relationships between perceived teachers' controlling behaviors and amotivation in physical education. Journal of Teaching in Physical Education, 37(2), 197-208.

Levy, A.R., Polman, R.C., \& Borkoles, E. (2008). Examining the relationship between perceived autonomy support and age in the context of rehabilitation adherence in sport. Rehabilitation Psychology, 53(2), 224-230.

Li, C., Yuan, Z., Clements-Nolle, K., Fu, Y., Deadmond, M., \& Yang, W. (2018). Physical activity and overweight/obesity among academic stressed adolescents. Biostatistics and Epidemiology International Journal, 1(2), 40-46.

Lim, B.C., \& Wang, C.J. (2009). Perceived autonomy support, behavioural regulations in physical education and physical activity intention. Psychology of Sport and Exercise, 10(1), 52-60.

Nicholls, J.G. (1989). The competitive ethos and democratic education. Harvard University Press.

Otis, N., Grouzet, F.M., \& Pelletier, L.G. (2005). Latent motivational change in an academic setting: a 3-year longitudinal study. Journal of Educational Psychology, 97(2), 170-183.

Papaioannou, A. (1994). Development of a questionnaire to measure achievement orientations in physical education. Research Quarterly for Exercise and Sport, 65(1), 11-20.

Papaioannou, A. (1997). Perceptions of motivational climate, perceived competence, and motivation of students of varying age and sport experience. Perceptual and Motor Skills, 85(2), 419-430.

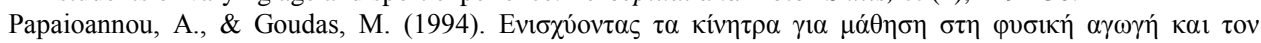
$\alpha \theta \lambda \eta \tau \iota \sigma \mu o ́$ (Enhancing motivation for learning in physical education and sports). Sports and Society, 8 , 69-77. In Greek

Papaioannou, A., \& Theodorakis, Y. (1996). A test of three models for the prediction of intention for participation in physical education lessons. International Journal of Sport Psychology, 27(4), 383-399.

Pate, R.R., Schenkelberg, M. A., Dowda, M., \& McIver, K.L. (2019). Group-based physical activity trajectories in children transitioning from elementary to high school. BMC Public Health, 19(1), 323. 
Pelletier, L.G., Fortier, M.S., Vallerand, R.J., Tuson, K.M., Briére, N.M., \& Blais, M.R. (1995). Toward a new measure of intrinsic motivation, extrinsic motivation, and amotivation in sports: The Sport Motivation Scale (SMS). Journal of Sport and Exercise Psychology, 17(1), 35-53.

Ryan, R.M., \& Connell, J.P. (1989). Perceived locus of causality and internalization: Examining reasons for acting in two domains. Journal of Personality and Social Psychology, 57(5), 749-761.

Ryan, R.M., \& Deci, E.L. (2008). Self-determination theory and the role of basic psychological needs in personality and the organization of behavior. In O.P. John, R.W. Robins, \& L.A. Pervin (Eds.), Handbook of personality: Theory and research, (pp. 654-678). The Guilford Press.

Ryan, R.M., \& Deci, E.L. (2017). Self-determination theory: Basic psychological needs in motivation, development, and wellness. Guilford Publications.

Sallis, J.F., \& McKenzie, T.L. (1991). Physical education's role in public health. Research Quarterly for Exercise and Sport, 62(2), 124-137.

Sallis, J.F., \& Patrick, K. (1994). Physical activity guidelines for adolescents: consensus statement. Pediatric Exercise Science, 6(4), 302-314.

Sallis, J.F., Patterson, T.L., Buono, M.J., \& Nader, P.R. (1988). Relation of cardiovascular fitness and physical activity to cardiovascular disease risk factors in children and adults. American Journal of Epidemiology, 127(5), 933-941.

Sallis, J.F., Prochaska, J.J., \& Taylor, W.C. (2000). A review of correlates of physical activity of children and adolescents. Medicine and Science in Sports and Exercise, 32(5), 963-975.

Shephard, R.J., \& Trudeau, F. (2000). The legacy of physical education: Influences on adult lifestyle. Pediatric Exercise Science, 12(1), 34-50.

Soini, M. (2006). Motivaatioilmaston yhteys yhdeksäsluokkalaisten fyysiseen aktiivisuuteen ja viihtymiseen liikuntatunneilla (The relationship of motivational climate to physical activity intensity and enjoyment within ninth grade pupils in school physical education classes). Doctoral thesis, University of Jyväskylä, Jyväskylä. In Finnish

Steinmayr, R., Bipp, T., \& Spinath, B. (2011). Goal orientations predict academic performance beyond intelligence and personality. Learning and Individual Differences, 21(2), 196-200.

Sun, H., Li, W., \& Shen, B. (2017). Learning in physical education: A self-determination theory perspective. Journal of Teaching in Physical Education, 36(3), 277-291.

Taylor, I.M., \& Lonsdale, C. (2010). Cultural differences in the relationships among autonomy support, psychological need satisfaction, subjective vitality, and effort in British and Chinese physical education. Journal of Sport and Exercise Psychology, 32(5), 655-673.

Telama, R., Yang, X., Laakso, L., \& Viikari, J. (1997). Physical activity in childhood and adolescence as predictor of physical activity in young adulthood. American Journal of Preventive Medicine, 13(4), 317-323.

Trouilloud, D., Sarrazin, P., Bressoux, P., \& Bois, J. (2006). Relation between teachers' early expectations and students' later perceived competence in physical education classes: Autonomy-supportive climate as a moderator. Journal of Educational Psychology, 98(1), 75-86.

Vallerand, R.J. (1997). Toward a hierarchical model of intrinsic and extrinsic motivation. In M.P. Zanna (Ed.), Advances in experimental social psychology, (Vol. 29, pp. 271-360). New York: Academic Press.

Vallerand, R.J., Fortier, M.S., \& Guay, F. (1997). Self-determination and persistence in a real-life setting: Toward a motivational model of high school dropout. Journal of Personality and Social Psychology, 72(5), 1161.

van Langen, A., Bosker, R., \& Dekkers, H. (2006). Exploring cross-national differences in gender gaps in education. Educational Research and Evaluation, 12(2), 155-177.

Vlachopoulos, S., Biddle, S., \& Fox, K. (1996). A social-cognitive investigation into the mechanisms of affect generation in children's physical activity. Journal of Sport and Exercise Psychology, 18(2), 174-193.

Williams, L. (1994). Goal orientations and athletes' preferences for competence information sources. Journal of Sport and Exercise Psychology, 16(4), 416-430.

Wright, M.T., Patterson, D.L., \& Cardinal, B.J. (2000). Increasing children's physical activity. Journal of Physical Education, Recreation \& Dance, 71(1), 26-29.

Xiang, P., Lee, M., \& Shen, J. (2001). Conceptions of ability and achievement goals in physical education: Comparisons of American and Chinese students. Contemporary Educational Psychology, 26, 348-365.

Zhang, X., Gu, X., Keller, J., \& Chen, Q. (2019). Understanding physical activity behavior of Chinese female college students with/without vulnerable conditions: a theory of planned behavior perspective. Women \& Health, 59(8), 907-920. 


\section{OPAŽENA AUTONOMIJA, MOTIVACIONA KLIMA I INTENCIJA PREMA FIZIČKOJ AKTIVNOST: UPOREDNO ISTRAŽIVAWE STUDENATA NA OSNOVU POLA I NIVOA OBRAZOVANJA}

Glavni cilj ovog istraživanja bio je da se ispita da li se opažena autonomija tokom nastave fizičkog vaspitanja (FV), opažena motivacija i namere učenika prema fizičkim aktivnostima izvan škole razlikuju u skladu sa njihovim obrazovnim nivoom i polom. Uzorak se sastojao od 551 dece (266 dečaka i 285 devojčica), od kojih je 320 išlo u osnovnu školu, a 231 u srednju. Za prikupljanje podataka korišćena su četiri instrumenta: (a) demografski upitnik; (b) skala opažene autonomije u fizičkom vaspitanju (prema engl. Perceived Autonomy Support-P.A.S. u FV) za ocenjivanje motivacije učenika; c) Upitnik za ocenu opažene motivacione klime u okviru nastave fizičkog vaspitanja (prema engl. Learning and Performance Orientations in Physical Education Classes Questionnaire-LAPOPECQ) $i(d)$ upitnik zasnovan na Teoriji razumnog delovanja kojim su ocenjivane intencije učesnika ka fizičkom aktivnošću van škola. Rezultati su pokazali da kako deca odrastaju i menjaju obrazovni nivo, opažena motivaciona klima sa naglaskom na zadatak, osećaj autonomije u FV i namera za vežbanjem opadaju. Pored toga, činilo se da devojčice pokazuju manju nameru da vežbaju u poređenju sa dečacima, posebno u najvišem stepenu obrazovanja, i više verovatno doživljavaju motivacionu klimu na časovima FV kao orijentisanu na zadatak, a ne na ego. Ukratko, pol i obrazovni nivo učenika smatraju se kao dva ključna faktora za motivaciju i osećaj autonomije u obrazovanju, kao i za njihovu nameru da vežbaju van škole.

Ključne reči: motivaciona klima, opažena autonomija, namera fizičke aktivnosti, obrazovni nivo, pol 